\title{
Effectiveness assessment of a therapeutic programme for women with overweight and obesity: a biopsychosocial perspective
}

\author{
JOANNA SZCZEPAŃSKA-GIERACHA ${ }^{1, A-E, ~}$, , JUSTYNA MAZUREK ${ }^{2, E, F}$, ANNA SERWETA $^{1, в}$, \\ ORCID ID: 0000-0001-5191-3799 $\quad$ ORCID ID: 0000-0001-8983-0286 ' ORCID ID: 0000-0002-7699-6890 \\ KRYSTYNA BOROŃ-KRUPIŃSKA ${ }^{3, E, ~ F, ~ J O A N N A ~ K O W A L S K A ~}{ }^{1, ~ c, ~ F, ~ A N N A ~ S K R Z E K ~}$
ORCID ID: 0000-0002-1710-7547 \\ ${ }^{1}$ Department of Physiotherapy, University School of Physical Education, Wroclaw, Poland \\ ${ }^{2}$ Department and Division of Medical Rehabilitation, Wroclaw Medical University, Poland \\ ${ }^{3}$ Department of Faculty of Physical Education, University School of Physical Education, Wroclaw, Poland
}

A - Study Design, B - Data Collection, C - Statistical Analysis, D - Data Interpretation, E - Manuscript Preparation, F - Literature Search, G - Funds Collection

Summary Background. The commonly observed prevalence of increasing overweight and obesity, particularly among older women with coexisting symptoms of depression and high stress level, is a motivation to undertake comprehensive therapeutic actions.

Objectives. The goal of this study was to assess the effectiveness of a therapeutic programme for women with overweight and obesity from the biopsychosocial perspective.

Material and methods. An observational study was conducted at the Foundation for Senior Citizen Activation SIWY DYM, Poland. 42 women from 60 to 88 years of age were qualified for the project, the mean value of Body Mass Index amounted to $30.65 \mathrm{~kg} / \mathrm{m}^{2}$, $48 \%$ of the women were diagnosed as overweight, and $40 \%$ were diagnosed as obese. The Satisfaction with Life Scale, the Geriatric Depression Scale and the Perception of Stress Questionnaire were used to assess the emotional state of the programme participants. Results. The therapeutic programme proved to be effective in all studied areas: reduction of body mass, reduction of depression symptoms and reduction of stress level. A statistical significance was recorded in mood improvement along with a decrease in stress level in the whole group. The subjects who at the moment of joining the therapeutic programme showed the most severe symptoms of depression demonstrated the highest mood improvement. At the end of the research project, there was no case of severe symptoms of depression. The greatest benefits were experienced by older women and those with low life satisfaction at the beginning of the treatment.

Conclusions. The therapeutic programme addressed to older women with overweight and obesity proved to be efficient in the biopsychosocial aspect.

Key words: depression, psychotherapy, health promotion, aged, self-help groups, obesity.

Szczepańska-Gieracha J, Mazurek J, Serweta A, Boroń-Krupińska K, Kowalska J, Skrzek A. Effectiveness assessment of a therapeutic programme for women with overweight and obesity: a biopsychosocial perspective. Fam Med Prim Care Rev 2019; 21(4): 381-386, doi: https://doi.org/10.5114/fmpcr.2019.90172.

\section{Background}

Lifestyle diseases, also known as chronic or non-communicable diseases, are rapidly becoming the epidemics of the $21^{\text {st }}$ century. They affect all social groups, irrespective of their age, nationality or social class. The prevalence of these disorders is related to the development of our civilization, which is the reason why they are more frequently recorded in affluent countries with higher economic development. In 2007 , over $60 \%$ of deaths were caused by lifestyle diseases, including their complications, long-term consequences and sequelae, and $44 \%$ of them were premature deaths that took the lives of young people. In Poland, the percentage of deaths caused by lifestyle diseases reached $89 \%$ in 2011 [1]. The classification of the most lethal lifestyle diseases publicised by the World Health Organization (WHO) included coronary heart diseases, cancers, pulmonary tract diseases, diabetes, mental disorders, obesity, depression and addictions to alcohol and smoking [2,3]. The consequences of the increase in the prevalence of non-communicable diseases are mostly visible among elderly people, who apart from the limitations resulting from ageing, are additionally affected by numerous lifestyle-induced health conditions.
According to the biopsychosocial model, a disease is the outcome of an interaction of the biological, emotional and environmental factors of an individual. Thus, a holistic approach in the treatment of any condition should include all three dimensions: biological, psychological and social. The first refers to the direct impact of a disease on the human body, i.e. physical changes which can be diagnosed and treated by medicine. The psychological dimension signifies emotional and cognitive problems, as well as mental disorders, which may be either the cause of a disease or may occur concurrently with a somatic condition. The social dimension deals with the fact that functioning in society, adopting social roles and maintaining good relations with other people all have an impact on a person's health. In the holistic approach, spirituality, related to personal beliefs and religious practices, also has a huge influence on an individual's quality of life [4].

Relevant support and acceptance from the social environment in the biopsychosocial model facilitate therapy and improves the patient's quality of life. In the biopsychosocial model, lifestyle diseases are caused by the coexistence of many factors detrimental to health (such as a sedentary lifestyle, wrong diet, high level of stress and social isolation); therefore, effective 
treatment should include a wide range of long-term health promoting activities which will help to minimise the already existing damage and improve quality of life [5].

\section{Objectives}

The purpose of the presented study was to assess the efficiency of a therapeutic programme for women with overweight or obesity from the biopsychosocial perspective, as well as to identify the areas of the most significant changes resulting from comprehensive health-promoting activities.

\section{Material and methods}

The observational study was conducted at the Foundation for Senior Activation in Wroclaw, Poland. The study group included women who, having read the information in local media, volunteered to participate in this project addressed to people with overweight and obesity or those who wanted to take care of their health. The project was financed by the Foundation for Senior Activation and the Wroclaw Municipality. All subjects were qualified for the study according to the 'first come, first served' principle.

\section{Participants}

The recruitment process lasted for four weeks. The inclusion criteria were: age equal or higher than 60 , willingness to reduce weigh or improve health and physical fitness, the presence of at least two of the five indicators for a metabolic syndrome (according to the National Cholesterol Education Program, Adult Treatment Panel, NCEP-ATP III), written statement from their physician confirming a lack of health-related contraindications to undertake physical activity, signed written consent to participate in the study.

\section{Intervention}

Over the course of the therapeutic programme, all the participants attended support group meetings (twice a week, 60 minutes each time). Within these meetings, they took part in general fitness training (40 minutes), as well as health-promoting education and psychoeducation (20 minutes). Each class was conducted by a physiotherapist and a psychotherapist in a small, fixed group of 10-12 women. Apart from the participation in the general fitness group led by a coach, the women were encouraged to take up individual health-promoting activities (60-minute outdoor hike once a week). To document such activity, participants were asked to keep physical activity diaries. As a part of education activities, participants were encouraged to modify their diets: to reduce white flour and sugary foods and increase the consumption of healthy oils and vegetables in their daily menu.

Each meeting of the support group was attended by a psychotherapist to accelerate and strengthen the natural processes of building inter-personal links in the group in addition to modelling and strengthening attitudes of openness, collaboration and mutual support in the execution of joint goals. Furthermore, the psychotherapist also facilitated the social activation of the participants. Activities undertaken by the psychotherapist contributed not only to building a friendly, supportive atmosphere during the classes, but also to social activation of the participants outside the classes (for example, going to the movies or for a walk together, joint trips out of town). As a result of the cooperation between the physiotherapist and psychotherapist, each meeting of the support group merged an element of physical activation with the therapeutic aspects, resulting in increased motivation to active participation in the group classes.

\section{Data collection}

At the time of joining the project, the participants' up-to-date laboratory test results were recorded (including levels of glucose, cholesterol and triglycerides). Additionally, their anthropomorphic measurements were taken: body mass, height (necessary to determine the Body Mass Index - BMI), waist and hip circumferences (necessary to determine the Waist-Hip Ratio - WHR). The results were recorded with an accuracy to one decimal point. Waist circumference $\geq 88 \mathrm{~cm}$ was diagnosed as abdominal obesity, $\mathrm{BMI} \geq 25$ was diagnosed as overweight, and $\mathrm{BMI} \geq 30$ was diagnosed as obesity.

Upon being accepted for the project, the women also filled in the Satisfaction With Life Scale (SWLS) to assess their current level of satisfaction with life [6], the Geriatric Depression Scale (GDS-15) to assess the emotional condition [7] and the Perception of Stress Questionnaire (PSQ) to assess the level of stress. The SWLS includes 5 questions, and the result represents a current general indicator of life satisfaction, where the higher the result, the greater the satisfaction with life [8]. The GDS is the most frequently applied scale to assess the psychological condition of individuals, their mood, sense of happiness or lack of it. In the 15-question version, a result ranging from 0 to 5 points means no depression, while a score of 6 points and above signifies depression of varying severity [7]. The PSQ comprises 27 statements, to which a respondent applies one of 5 options, where the extreme answers refer to "true" or "false", respectively. The total result reflects the perception of the general stress level. The higher the score, the higher the sense of stress [9]. The GDS, PSQ and body mass were measured again after 3 months of systematic participation in the therapeutic programme.

\section{Ethical consideration}

All the participants were informed about the character and the purpose of the project, as well as about the rules of participation, including the possibility to resign at any stage without any consequences. Approval from the Bioethics Committee of the University School of Physical Education in Wrocław was obtained.

After the recruitment period, the key phase of the project (treatment period) began, lasting 12 weeks, and was followed by the final phase of the study - end tests.

\section{Statistical analysis}

For the purpose of statistical analysis, descriptive statistical tools were applied: mean, standard deviation, minimum and maximum values and, in the case of qualitative variables, also total count and percentages. In relation to normal data distribution, to compare the changes that occurred during the project (initial and final measurement results), the Student's $t$-test for paired samples was applied. To analyse the relations between selected numerical variables, the Pearson's correlation test was used. Statistical tests were verified according to a significance level of $p<0.05$

\section{Results}

\section{Socio-demographic and clinical characteristics}

42 women were qualified for the project, the age ranging from 60 to $88(69.82 \pm 7.21)$, and $42 \%$ of the whole group were people over $70.45 \%$ of the group declared secondary education, $28 \%$ university education, and $27 \%$ declared primary education. At the moment of joining the therapeutic programme, the mean body mass in the studied group was 78.37 ( \pm 17.0$)$ kilograms (kg). At an average height of 159.54 ( \pm 6.27 ) centimetres $(\mathrm{cm})$, the mean value of $\mathrm{BMI}$ amounted to $30.65( \pm 5.86)$ kilogram per metre square $\left(\mathrm{kg} / \mathrm{m}^{2}\right) .48 \%$ of the subjects were 
diagnosed overweight, and $40 \%$ were diagnosed as obese. The mean result of the WHR was $0.87( \pm 0.08)$. The studied group was diversified with respect to arterial hypertension and laboratory test parameters (glucose level, total cholesterol, HDL and LDL fractions, triglycerides). The collected data is presented in Table 1.

\begin{tabular}{|c|c|c|c|c|}
\hline \multicolumn{2}{|l|}{ Feature } & Mean & SD & Minimum \\
\hline \multirow{2}{*}{$\begin{array}{l}\text { Blood pressure } \\
{[\mathrm{mm} \mathrm{Hg}]}\end{array}$} & systolic & 134.42 & 23.14 & 90 \\
\hline & diastolic & 74.54 & 10.9 & 52 \\
\hline \multirow{3}{*}{$\begin{array}{l}\text { Cholesterol } \\
{[\mathrm{mg} / \mathrm{dl}]}\end{array}$} & total & 208.36 & 42.89 & 144 \\
\hline & $\mathrm{HDL}$ & 65.02 & 14.22 & 42 \\
\hline & LDL & 124.41 & 37.65 & 63 \\
\hline \multicolumn{2}{|c|}{ Triglycerides [mg/dl] } & 121.28 & 48.53 & 48 \\
\hline \multicolumn{2}{|c|}{ Blood sugar level [mg\%] } & 101.55 & 16.32 & 60 \\
\hline
\end{tabular}

HDL - High-Density Lipoprotein, LDL - Low-Density Lipoprotein, SD - Standard Deviation.

According to up-to-date recommendations, the test results showed the presence of indicators of a metabolic syndrome and the necessity to undertake therapeutic procedures to reduce this. Arterial hypertension was identified in 26 people. $88 \%$ of them were treated, and this was not a contraindication for participation in the project. Diabetes was the most serious condition requiring specialist treatment. Of the 7 identified cases of diabetes, $71 \%$ were treated. Of the 21 people with high cholesterol level, $52 \%$ were treated. 12 people had high triglyceride levels, $58 \%$ of whom were treated.

The general level of satisfaction with life in the studied group, assessed with the SWLS questionnaire, ranged from 11 to 32 , with the mean value equal to $20( \pm 4.81)$. The majority of participants showed an average level of life satisfaction, placed in a score range from 16 to 25 (69\%). Almost 30\% of the group assessed their life satisfaction as high. Only 1 participant's score equalled 11 points, indicating low life satisfaction. Intensified symptoms of depression assessed with the GDS-15 at the moment of joining the project were identified in 12 women (28\%), 1 of whom, with the score of 12 points, manifested severe mood disorders. The other 30 participants did not show any symptoms of mood disorders (GDS $>6$ ). The mean score value of the whole group amounted to $4.32( \pm 2.91)$. The mean value of the stress level, assessed with the PSQ, amounted to 59.16 ( \pm 15.15$)$.

\section{Intervention effect}

After 3 months of participation in the project, the emotional condition of the women from the studied group improved. A sta- tistical significance was recorded in the reduction of symptoms of depression $(p=0.006)$ in addition to a decrease of stress level $(p=0.002)$ in the whole group. At the beginning of the project, severe symptoms of depression (GDS-15 >5) were identified in the case of 12 women (28\%). At the end of the therapeutic programme only 4 subjects still suffered from depression but mild depression not severe. The change was statistically significant $(p<0.001)$ (Table 2).

\begin{tabular}{|c|c|c|c|c|c|c|}
\hline Feature & | Test & Mean & SD & $\begin{array}{l}\text { Mean } \\
\text { change }\end{array}$ & $\begin{array}{l}\text { Stu- } \\
\text { dent's } \\
t \text {-test }\end{array}$ & $p$ \\
\hline \multirow{2}{*}{$\begin{array}{l}\text { GDS value } \\
\text { in the whole } \\
\text { group }\end{array}$} & $\begin{array}{l}\text { initial } \\
(n=44)\end{array}$ & 4.32 & 2.91 & \multirow[t]{2}{*}{-1.15} & \multirow[t]{2}{*}{2.90} & \multirow[t]{2}{*}{0.006} \\
\hline & $\begin{array}{l}\text { final } \\
(n=44)\end{array}$ & 3.21 & 1.84 & & & \\
\hline \multirow{2}{*}{$\begin{array}{l}\text { GDS value } \\
\text { for people } \\
\text { whose initial } \\
\text { result was } \\
\text { higher than } \\
5 \text { points in } \\
\text { GDS }\end{array}$} & $\begin{array}{l}\text { initial } \\
(n=12)\end{array}$ & 8.2 & 1.63 & \multirow[t]{2}{*}{-4.02} & \multirow[t]{2}{*}{6.51} & \multirow[t]{2}{*}{$<0.001$} \\
\hline & $\begin{array}{l}\text { final } \\
(n=4)\end{array}$ & 4.26 & 1.7 & & & \\
\hline \multirow{2}{*}{$\begin{array}{l}\text { Stress level } \\
\text { in the whole } \\
\text { group (PSQ) }\end{array}$} & $\begin{array}{l}\text { initial } \\
(n=44)\end{array}$ & 59.16 & 15.15 & \multirow[t]{2}{*}{-6.41} & \multirow[t]{2}{*}{3.33} & \multirow[t]{2}{*}{0.002} \\
\hline & $\begin{array}{l}\text { final } \\
(n=44)\end{array}$ & 52.69 & 14.44 & & & \\
\hline
\end{tabular}

DS - Geriatric Depression Scale, PSQ - Perception of Stress Questionnaire, SD - Standard Deviation.

In the case of $62 \%$ of women from the studied group, there was a drop in body mass and BMI; however, there were also women who put on weight over the course of the project. As a result, the mean value of body mass and BMI in the whole group was reduced; however, the difference was not statistically significant.

Analysis of the correlations showed a statistically significant relationship between the GDS and the PSQ results. There were no significant interdependencies in the values of the BMI, WHR and GDS or PSQ between the initial and final measurements. The detailed results are shown in Table 3.

To define the profile of women who experienced the best effects, as well as of those whose condition changed the least, the studied group $(n=42)$ was divided into two subgroups: A - women for whom at least two results of BMI, GDS or PSQ improved, B - women for whom at least two results did not improve. Subgroup A (with at least two positive effects) included twice as many participants $(n=29)$ as subgroup B (lack of at least

\begin{tabular}{|c|c|c|c|c|c|c|}
\hline \multirow[b]{2}{*}{ Variable } & \multicolumn{6}{|c|}{ Initial measurement } \\
\hline & Body mass & Waist circumference & Hip circumference & WHR & BMI & GDS-15 \\
\hline Body mass & & 0.76 & 0.9 & -0.1 & 0.92 & 0.21 \\
\hline Waist circumference & 0.88 & & 0.7 & 0.48 & 0.81 & -0.03 \\
\hline Hip circumference & 0.93 & 0.89 & & -0.29 & 0.87 & 0.14 \\
\hline WHR & 0.13 & 0.47 & 0.001 & & -0.01 & -0.19 \\
\hline BMI & 0.92 & 0.91 & 0.91 & 0.23 & & 0.15 \\
\hline GDS-15 & 0.13 & 0.12 & 0.2 & -0.07 & 0.15 & \\
\hline \multirow[t]{2}{*}{ PSQ } & 0.16 & 0.07 & 0.15 & -0.11 & 0.06 & 0.57 \\
\hline & \multicolumn{6}{|c|}{ Final measurement } \\
\hline
\end{tabular}

WHR - Waist-Hip Ratio, BMI - Body Mass Index, GDS - Geriatric Depression Scale, PSQ - Perception of Stress Questionnaire. 
two positive effects, $n=13$ ). Such a great difference recorded in the subgroup size is a promising result and may be evidence of the efficiency of the conducted therapeutic programme.

Additionally, it was shown that a reduced BMI was recorded first of all, among the older women (more than 70 years old). The difference of the mean age of the women with an improvement of the BMI and of women without any improvement of the BMI equalled over 6 years $(p=0.006)$. The greatest improvement of mood was observed in the case of women who joined the project with low life satisfaction $(p=0.022)$ (Table 4).

\begin{tabular}{|c|c|c|c|c|c|}
\hline \multirow{2}{*}{$\begin{array}{l}\text { Parameter } \\
\text { or variable }\end{array}$} & \multirow[t]{2}{*}{ Change } & \multicolumn{2}{|l|}{ Age } & \multicolumn{2}{|l|}{ SWLS } \\
\hline & & Mean & $p$ & Mean & $p$ \\
\hline \multirow[t]{2}{*}{ BMI } & improvement & 72.14 & \multirow[t]{2}{*}{0.006} & 22.66 & \multirow[t]{2}{*}{0.590} \\
\hline & $\begin{array}{l}\text { lack of im- } \\
\text { provement }\end{array}$ & 66.03 & & 23.64 & \\
\hline \multirow[t]{2}{*}{ GDS } & improvement & 69.85 & \multirow[t]{2}{*}{0.990} & 21.54 & \multirow[t]{2}{*}{0.022} \\
\hline & $\begin{array}{l}\text { lack of im- } \\
\text { provement }\end{array}$ & 69.81 & & 24.82 & \\
\hline \multirow[t]{2}{*}{ KPS } & improvement & 69.87 & \multirow[t]{2}{*}{0.884} & 22.81 & \multirow[t]{2}{*}{0.565} \\
\hline & $\begin{array}{l}\text { lack of im- } \\
\text { provement }\end{array}$ & 69.55 & & 23.7 & \\
\hline
\end{tabular}

BMI - Body Mass Index, GDS - Geriatric Depression Scale, PSQ - Perception of Stress Questionnaire, SWLS - Satisfaction With Life Scale.

\section{Discussion}

The therapeutic programme for women with overweight and obesity proved to be efficient mostly in the emotional sphere. The greatest improvement was observed in stress and mood levels. Almost $70 \%$ of the project participants experienced a reduction of felt stress, on average by 6.38 points. This could be possible thanks to several complementary factors, which include: support from the psychotherapist, established group relationships, friendly atmosphere of mutual acceptance and social integration. Moreover, the psycho-educational part of the conducted classes allowed the participants to understand the factors amplifying their stress, as well as to improve their skills of coping with mental tension. The women learned how to relax in a healthy way through physical activity rather than by excessive eating. Therefore, after 3 months of the project duration, the greatest reduction was observed in the stress level.

Symptoms of depression can greatly delay the process of physiotherapy and determine the evaluation of its effectiveness [10]. The therapeutic programme also turned out to be effective with respect to the reduction of symptoms of depression, and the recorded change was statistically significant. Classes conducted for only 3 months reduced the number of women with mood disorder symptoms by $66 \%$, with the highest efficacy among the women who at the moment of joining the project showed intensified symptoms of depression $(p<0.001)$. It should be stressed that during the research project, none of the women took antidepressant medications. The statistical analysis showed a significant relationship between mood improvement and reduction of the stress level. The recorded efficiency of the project is evidence of a good selection of therapeutic intervention. Intensive work focused on the reduction of psychophysical tension might induce the reduction of body weight in the subsequent months of the therapeutic programme. Similar research results were obtained by Trief et al. [11].

The importance of physical activity is also worth mentioning in the context of mental state. Weber-Rojek et al. [12] emphasised the relationship between well-being and physical activity, which, according to the authors, is the principal factor in re- ducing excessive body mass and, at the same time, increasing a feeling of attractiveness and improving one's mental condition. Costa et al. [13] observed that elderly people with mood disorders show lower physical activity in comparison to the group without mood disorders. A lack of regularly undertaken physical activity contributes to the accumulation of fat tissue [13]. The research conducted by Yoshida et al. [14] confirms the prevalence of depression among people who less frequently undertake physical activity in comparison to people without depression. This means that depression results in a reluctance to undertake physical activities, which in turn leads to a constant high body mass index. On the other hand, a high stress level and, related to it, less effective slimming efforts lead to an increase in depression [15].

Studies show that people attending weight loss programmes expect to eliminate from $9 \%$ to $25 \%$ of initial body mass [16] or to lose from $10 \mathrm{~kg}$ in 4 months to $20 \mathrm{~kg}$ in 2 years [17]. Unrealistic expectations are rarely possible to achieve in therapeutic activities based on dietary and behavioural education [16]. According to Tan and Wong, in the case of adults, the elimination of ca. 3-5 kg of weight within 4 months (when applying training combined with a diet) seems to be a realistic goal [17]. In the described therapeutic programme, the most important principle was the biopsychosocial aspect providing an opportunity to change one's lifestyle, establish social relations, improve one's mood and reduce the stress level, and not a rapid elimination of fat tissue.

In this study, $62 \%$ of women observed a reduction in their body weight. Unfortunately, in the case of some women, their body mass increased. Overweight people tend to treat eating as a reward for an undertaken effort. Additional meals might become the prize for an undertaken physical activity that had been absent in their lives up to the moment of joining the programme. This is very important to remember in future therapeutic activities. In the programme in question, knowledge of this relationship was missing, which might have had an impact on the overall results for the whole group, showing a lack of significant changes in this area. It should also be kept in mind that 12 weeks is a very short period to obtain a reduction of body mass in the case of women of postmenopausal age. For many women, their goal was to stop the increase in body weight that they had observed over the previous months or even years. Generally, elderly people need a longer time to reduce the first 2-3 kilograms; therefore, reducing the BMI was not the most important goal of the therapeutic programme. Attempts to eliminate weight, accompanied by frequent weight control, may intensify mental disorders, contributing to stress and intense symptoms of depression. A meta-analysis conducted by Benn et al. [18] showed a statistically significant relationship between a poor mental condition and frequent weight self-control. This means that checking body weight may cause self-devaluation, an increased stress level and a sense of shame [19].

In our opinion, applying a special diet intensifies stress and leads to an increased intake of high-calorie products. Such interdependence was observed by Carpenter et al. [20], who showed that "stress eating" primarily concerns people with dietary restrictions focused on body mass reduction. Such disturbing reports influenced the direction of actions in the therapeutic programme, focusing on a non-dieting approach excluding any carefully planned diet with calculations of calories and weights of daily food ratios in favour of education and talks on the beneficial role of physical activity in general. The non-dieting approach proposed in the mentioned programme, as well as the application of techniques allowing one to reduce mental tensions to focus, first of all, on improving one's emotional state, as in the research by Christaki et al. [21], were probably the factors which contributed to the recorded improvement in the emotional sphere.

Ibrahim et al. [22], in their research, observed that an increase of felt stress by 5 points corresponds to an increase in 
body mass by $0.95 \mathrm{~kg}$ over a period of 7 months. They justified the changes with activation of the HPA axis and the impact of strong stress on increased appetite. Furthermore, the research conducted by Trief et al. [11] indicates that the presence of emotional tension hinders the elimination of weight (high level of stress facilitates body mass increase). According to this research, we assume that mood improvement will result in a reduction of body weight over subsequent months. This motivates the authors and implementers of this therapeutic programme to continue to follow up the results for many months or even years.

In summary, it should be stressed that the therapeutic programme turned out to be most effective in the case of elderly women (more than 70 years of age), who presented with a worse psychophysical condition at the moment of joining the programme. This is a very important observation, since in this age group, it is most difficult to achieve significant changes and maintain them in the long term. At the same time, we are convinced that without the participation of younger women with a better psychophysical condition in the group, it would have been difficult to achieve such high effectiveness of the undertaken activities, since these women brought in a lot of energy and set an example to follow for other participants in worse psychophysical condition.

\section{Limitations of the study}

The biggest limitation of the research project was the lack of a control group. This was due to the fact that the therapeutic programme was financed from the public funds of Wrocław Municipality, and every person joining in had to receive help and appropriate treatment. It was impossible to establish a control group (without therapeutic support). Thus, the research project had an observational character and was not a clinically controlled trial.

\section{Implication for clinical practice}

Healthcare providers should regularly pay attention to non-pharmacological treatment for women with overweight and obesity.

\section{Conclusions}

1. The therapeutic programme addressed to women with overweight and obesity proved to be efficient in the biopsychosocial aspect.

2. The highest effectiveness of the project was observed with respect to mood improvement and reduction of stress level, which constitutes a positive circumstance for normalisation of body mass in the future.

3. The greatest benefits from participation in the therapeutic programme were enjoyed by older women $(70+)$ and those who showed low satisfaction with life at the moment of joining the programme.

Acknowledgments. The authors thank the Foundation for Senior Citizen Activation SIWY DYM, Wroclaw, Poland and the Wroclaw municipality for their support throughout the study.

Source of funding: This work was funded from the authors' own resources.

Conflicts of interest: The authors declare no conflicts of interest.

\section{References}

1. Bielecki W. Markery ryzyka przewlekłych chorób niezakaźnych (CNCD's) a proces modernizacji biomedycznej społeczeństwa-wyzwania i dylematy współczesności. In: Synowiec-Piłat M, Łaska-Formejster A, eds. Biologiczny wymiar życia populacji a jego socjologiczne interpretacje. Łódź: Wydawnictwo Uniwersytetu Łódzkiego; 2003: 197-199 (in Polish).

2. Boerma T, Mathers CD. The World Health Organization and global health estimates: improving collaboration and capacity. BMC Med 2015; 13: 50, doi: 10.1186/s12916-015-0286-7.

3. Naseem S, Khattak UK, Ghazanfar H, et al. Prevalence of non-communicable diseases and their risk factors at a semi-urban community, Pakistan. Pan Afr Med J 2016; 23: 151, doi: 10.11604/pamj.2016.23.151.8974.

4. Ostrzyżek A, Marcinkowski JT. Biomedyczny versus holistyczny model zdrowia a teoria i praktyka kliniczna. Probl Hig Epidemiol 2012; 93(4): 682-686 (in Polish).

5. Szczepańska-Gieracha J, Jaworska L, Mazurek J, et al. Ujęcie biopsychospołeczne w leczeniu depresji osób starszych. Gerontol Współcz 2017; 3(5): 108-113 (in Polish).

6. Pavot W, Diener E. Review of the satisfaction with life scale. Psychol Assessment 1993; 5(2): 164-172, doi: 10.1037/1040-3590.5.2.164.

7. Albiński R, Kleszczewska-Albińska A, Bedyńska S. Geriatryczna Skala Depresji (GDS). Trafność i rzetelność różnych wersji tego narzędzia - przegląd badan. Psychiatr Pol 2011; 45(4): 555-562 (in Polish).

8. Diener E, Emmons R, Larsen R, et al. The satisfaction with life scale. J Pers Assess 1985; 49: 71-75.

9. Plopa M, Makarowski R. Kwestionariusz Poczucia Stresu. Warszawa: Vizja Press \& It; 2010.

10. Kossakowska K, Szczepanik M, Woszczak M. Factors of subjective assessment of the effectiveness of physiotherapy: a study on patients with degenerative disease of the spine. Fam Med Prim Care Rev 2018; 20(2): 131-138. doi: 10.5114/fmpcr.2018.76455.

11. Trief PM, Cibula D, Delahanty LM, et al. Depression, stress and weight loss in individuals with metabolite syndrome in SHINE, a DPP translation study. Obesity (Silver Spring) 2014; 22(12): 2532-2538, doi: 10.1002/oby.20916.

12. Weber-Rojek M, Lubomska M, Radzimińska A, et al. The health behaviour of women Turing menopausal period. J Educ Health Sport 2016; 6(2): 151-162, doi: 10.5281/zenodo.46353.

13. Costa Branco J, Jansen K, Sobrinha JT, et al. Physical benefits and reduction of depressive symptoms among the elderly: results from the Portuguese "National Walking Program". Cienc Saude Coletiva 2015; 20(3): 1413-8123, doi: 10.1590/1413-81232015203.09882014.

14. Yoshida Y, Iwansa H, Kumagai S, et al. Longitudinal association between habitual physical activity and depressive symptoms in older people. Psychiatry Clin Neurosci 2015; 69(11): 686-692, doi: 10.1111/pcn.12324.

15. Elder ChR, Gullion ChM, Funk KL, et al. Impact of sleep, screen time, depression, and stress on weight loss phase of the LIFE study. Int J Obes (Lond) 2012; 36(1): 86-92, doi: 10.1038/ijo.2011.60.

16. Vallis M. Quality of life and psychological well-being in obesity management: improving the adds of success by managing distress. Int J Chin Pract 2016; 70(3): 196-205, doi: 10.1111/ijcp.12765.

17. Tan WJM, Wong TKM. Demographic profile, clinical characteristics, motivations and weight loss outcomes of patients in a nonsurgical weight management programme. Singapore Med J 2014; 55(3): 150-154, doi: 10.11622/smedj.2014035.

18. Benn Y, Webb TL, Chang BPI, et al. What is the psychological impact of self-weighing? A meta-analysis. Health Psychol Rev 2016; 10(2): 187-203, doi: 10.1080/17437199.2016.1138871. 
19. Duarte $C$, Matos M, Stubbs RJ, et al. The impact of shame, self-criticism and social rank of eating behaviours in overweight and obese women participating in a weight management programme. PLOS ONE 2017; 12(1): e0167571, doi: 10.1371/journal.pone.0167571.

20. Carpenter KM, Lovrjoy JC, Lange JM, et al. Outcomes and utilization of a low intensity workplace weight loss program. J Obes 2014; doi: https://doi.org/10.1155/2014/414987.

21. Christak E, Kokkinos A, Costarelli V, et al. Stress management can facilitate weight loss in Greek overweight and obese women: a pilot study. J Hum Nut Diet 2013; 26(1): 132-139, doi: 10.1111/jhn.12086.

22. Ibrahim M, Thearle MS, Krakoff J, et al. Perceived stress and anhedonia predict short-and long-term weight change, respectively in healthy adults. Eat Behav 2016; 21: 214-219, doi: 10.1016/j.eatbeh.2016.03.009.

Tables: 4

Figures: 0

References: 22

Received: 16.05.2019

Reviewed: 21.06 .2019

Accepted: 26.07.2019

Address for correspondence:

Justyna Mazurek, PhD, MD

Katedra i Zakład Rehabilitacji UM

ul. Borowska 213

50-556 Wrocław

Polska

Tel.: +48 695 180-984

E-mail: justyna.mazurek@umed.wroc.pl 